\title{
Dermatological Findings in Female and Male Fibromyalgia Patients
}

\author{
Müge Kepekçi ${ }^{1}$, (D) Berna Ürkmez ${ }^{2}$, () Emre Araz ${ }^{3}$, (i) Özgür Taşpınar ${ }^{4}$, Murat Erdugan ${ }^{5}$, \\ ilteriş Ahmet Şentürk ${ }^{6}$
}

${ }^{1}$ Department of Physical Therapy and Rehabilitation, University of Health Sciences Turkey, Kanuni Sultan Suleyman Health Aplication and Research Center, Istanbul, Turkey

${ }^{2}$ Department of Physical Therapy and Rehabilitation, University of Health Sciences Turkey, Haydarpaşa Numune Health Application and Research Center, Istanbul, Turkey

${ }^{3}$ Department of Dermatology, University of Health Sciences Turkey, Kanuni Sultan Suleyman Health Aplication and Research Center, Turkey ${ }^{4}$ Department of Physical Therapy and Rehabilitation, Adakent University, Istanbul, Turkey

${ }^{5}$ Department of Romatology, Istanbul Faculty of Medicine, Istanbul, Turkey

${ }^{6}$ Department of Algology, University of Health Sciences Turkey, Kanuni Sultan Suleyman Health Aplication and Research Center, Istanbul, Turkey

\begin{abstract}
Introduction: Fibromyalgia syndrome (FMS) is a chronic disease characterized by widespread musculoskeletal pain and hypersensitivity at some points of the body. Our study aims to investigate whether there is a difference between male and female FMS patients and male and female healthy volunteers concerning dermatological findings.

Methods: Sixty female and 60 male patients, who were diagnosed with FMS, were included in the study group; 60 female and 60 male healthy volunteers were included in the control group in this study. Fibromyalgia Impact Questionnaire and the Beck Depression Inventory were applied to all participants at the time of admission. All participants were examined by a dermatologist, and dermatological diagnoses were recorded. The results of the patients in both groups were compared and statistically analyzed.

Results: In the examination of dermatological diagnoses, it was found that the incidence of lichen simplex chronicus was significantly higher in female FMS patients than in healthy female participants ( $p=0.006)$.

Discussion and Conclusion: Based on the results of this study, our findings suggest that dermatological examination in patients with FMS should be given more importance within a holistic examination approach.

Keywords: Fibromyalgia syndrome; lichen simplex chronicus; skin.
\end{abstract}

F ibromyalgia syndrome (FMS) is a widespread and chronic disease characterized by chronic widespread musculoskeletal pain and hypersensitivity at some points of the body, which are called sensitive points ${ }^{[1]}$. FMS may accompany many disorders with a widespread pathogenetic mechanism, such as irritable bowel syndrome, chronic fa- tigue syndrome, anxiety, and depression ${ }^{[2]}$. Apart from these symptoms, pathological examination of the skin in patients with FMS revealed the presence of oxidative stress in the skin and various changes, such as an increased number of cytokines and mast cells ${ }^{[3]}$.

FMS is not considered to be a disorder with dermatological

Correspondence (iletişim): Berna Ürkmez, M.D. Saglik Bilimleri Universitesi, Haydarpasa Numune Saglik Uygulama ve Arastirma Merkezi, Fiziksel Tip ve Rehabilitasyon Klinigi, Istanbul, Turkey Phone (Telefon): +90 5062481353 E-mail (E-posta): drbernaurkmez@gmail.com Submitted Date (Başvuru Tarihi): 23.10.2018 Accepted Date (Kabul Tarihi): 04.11.2018 Copyright 2020 Haydarpaşa Numune Medical Journal OPEN ACCESS This is an open access article under the CC BY-NC license (http://creativecommons.org/licenses/by-nc/4.0/).

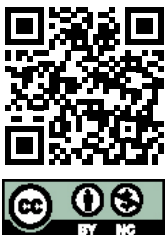


findings. However, several studies have shown that there are objective differences in the skin of patients with FMS compared with that of healthy subjects ${ }^{[4]}$. In particular, researchers have reported increased mast cell degranulation and increased mast cell count in the skin of patients with FMS compared with that of healthy volunteers ${ }^{[3]}$. Increased inflammatory cytokines in the skin [5], modified collagen metabolism due to the accumulation of collagen around peripheral nerves [6], cutaneous microcirculatory abnormalities ${ }^{[3,5]}$, autonomic nervous system dysfunction, and high levels of cutaneous opioid receptors ${ }^{[7]}$ have also been reported. All of these are considered to constitute the dermatological findings of FMS patients ${ }^{[8]}$.

In this study, our aim is to classify dermatological findings in male and female FMS patients and to determine whether there is any difference compared with the control group concerning dermatological diseases.

\section{Materials and Methods}

Patients who were admitted to Algology, Rheumatology, Physical Medicine, and Rehabilitation outpatient clinics and diagnosed with FMS based on the American College of Rheumatology (ACR) 2016 criteria $^{[9]}$ were included in this study. Sixty female and 60 male patients with FMS were included in the study group; 60 healthy female and 60 healthy male volunteers were included in the control group.

Demographic data of all participants were recorded. Fibromyalgia Impact Questionnaire (FIQ) and the Beck Depression Inventory (BDI) were completed for all participants. Skin examinations of all participants were performed by a dermatology specialist. The dermatological problems of all participants during the examination were recorded, and diagnostic skin diseases were determined and recorded.

Inclusion criteria consisted of diagnosis with FMS, ages of 30-50 years, and absence of major psychiatric disorders. Exclusion criteria were the presence of comorbid diseases that may be confused with FMS and may bring on suspicion in the differential diagnosis, presence of serious psychiatric problems, mental retardation, pregnancy or breastfeeding, diagnosis with cancer and receiving cancer treatment, and presence of rheumatic disease.

Informed consent forms were obtained from all participants. This study was approved by the local ethics committee.

\section{Statistical Analysis}

The categorical data were compared using the chi-square test and Fisher's exact test, and the results were presented together with number and frequency values. The normality of continuous data was examined using the Shapiro-
Wilk test. Since the data were not normally distributed, intergroup comparisons were performed using the MannWhitney $U$ test. Median (minimum-maximum) values were given as descriptive statistics for the groups. The level of statistical significance was $a=0.05$. The data were statistically analyzed using SPSS v22.

\section{Results}

Regarding demographic variables (age, marital status, and educational status), the groups were homogeneous among themselves ( $p>0.005)$ (Tables 1-3).

Table 1. Comparison of female group diagnosed with fibromyalgia syndrome and female control group

\begin{tabular}{|c|c|c|c|}
\hline & $\begin{array}{c}\text { FMS } \\
\text { Female }\end{array}$ & $\begin{array}{l}\text { Control } \\
\text { Female }\end{array}$ & $\mathbf{p}$ \\
\hline $\begin{array}{l}\text { Age median } \\
\text { (Min-Max) }\end{array}$ & $41(30-50)$ & $40(30-50)$ & 0.922 \\
\hline \multicolumn{4}{|l|}{ Marital status } \\
\hline Single & $11(9.2)$ & $11(9.2)$ & 1.000 \\
\hline Married & $46(38.3)$ & $47(39.2)$ & \\
\hline Widowed & $3(2.5)$ & $2(1.7)$ & \\
\hline \multicolumn{4}{|l|}{ Educational status } \\
\hline Elementary & $27(22.5)$ & $23(19.2)$ & \\
\hline Middle School & $19(15.8)$ & $16(13.3)$ & \\
\hline High School & $7(5.8)$ & $12(10)$ & 0.691 \\
\hline University & $3(2.5)$ & $3(2.5)$ & \\
\hline Doctorate & $4(3.3)$ & $6(5)$ & \\
\hline Beck median (Min-Max) & $28.5(20-40)$ & $14(7-30)$ & $<0.001$ \\
\hline FEQ median (Min-Max) & $34.5(25-50)$ & $21(15-39)$ & $<0.001$ \\
\hline \multicolumn{4}{|c|}{ Dermatological diagnoses, n (\%) } \\
\hline Dermographism & $2(1.7)$ & $0(0)$ & 0.496 \\
\hline Urticaria & $12(10)$ & $10(8.3)$ & 0.813 \\
\hline Melasma & $4(3.3)$ & $3(2.5)$ & 1.000 \\
\hline Tinea & $5(4.2)$ & $2(1.7)$ & 0.439 \\
\hline Raynaud phenomenon & $2(1.7)$ & $0(0)$ & 0.496 \\
\hline Neurotic excoriation & $5(4.2)$ & $3(2.5)$ & 0.717 \\
\hline Seborrheic dermatitis & $2(1.7)$ & $0(0)$ & 0.496 \\
\hline Contact dermatitis & $5(4.2)$ & $1(0.8)$ & 0.207 \\
\hline Acne & $3(2.5)$ & $2(1.7)$ & 1.000 \\
\hline Fibroma molle & $3(2.5)$ & $2(1.7)$ & 1.000 \\
\hline Lichen simplex chronicus & $13(10.8)$ & $2(1.7)$ & 0.006 \\
\hline Hair loss & $2(1.7)$ & $2(1.7)$ & 1.000 \\
\hline Molluscum contagiosum & $2(1.7)$ & $0(0)$ & 0.496 \\
\hline Rosacea & $3(2.5)$ & $2(1.7)$ & 1.000 \\
\hline Psoriasis & $0(0)$ & $1(0.8)$ & 1.000 \\
\hline Behçet's disease & $0(0)$ & $0(0)$ & - \\
\hline
\end{tabular}

Beck: Beck Depression Inventory; FIQ: Fibromyalgia Impact Questionnaire; FMS: Fibromyalgia Syndrome. 
There was no significant difference between female patients with FMS and healthy female participants concerning age $(p=0.922)$, marital status $(p=1.000)$, and educational status $(p=0.691)$. There was a statistically significant difference between female patients with FMS and healthy female participants concerning BDI and FIQ scores $(p<0.001, p<0.001)$. In the examination of dermatological diagnoses, there was a significant difference in patients diagnosed with lichen simplex chronicus concerning their distribution between the two groups $(p=0.006)$. There was no significant difference in the distribution of other dermatological diagnoses (Table 1).

Table 2. Comparison of the male group diagnosed with fibromyalgia syndrome and male control group

\begin{tabular}{|c|c|c|c|}
\hline & $\begin{array}{l}\text { FMS } \\
\text { Male }\end{array}$ & $\begin{array}{c}\text { Control } \\
\text { Male }\end{array}$ & $\mathbf{p}$ \\
\hline Age median (Min-Max) & $40(30-50)$ & $40(30-50)$ & 0.933 \\
\hline \multicolumn{4}{|l|}{ Marital status } \\
\hline Single & $12(10)$ & $11(9.2)$ & 1.000 \\
\hline Married & $45(37.5)$ & $46(38.3)$ & \\
\hline Widowed & $3(2.5)$ & $3(2.5)$ & \\
\hline \multicolumn{4}{|l|}{ Educational status } \\
\hline Elementary & $20(16.7)$ & $22(18.3)$ & \\
\hline Middle School & $20(16.7)$ & $19(15.8)$ & \\
\hline High School & $11(9.2)$ & $9(7.5)$ & 0.987 \\
\hline University & $4(3.3)$ & $5(4.2)$ & \\
\hline Doctorate & $5(4.2)$ & $5(4.2)$ & \\
\hline Beck median (Min-Max) & $22(9-40)$ & $15(9-30)$ & $<0.001$ \\
\hline FEQ median (Min-Max) & $32(17-50)$ & $24(14-36)$ & $<0.001$ \\
\hline \multicolumn{4}{|c|}{ Dermatological diagnoses, n (\%) } \\
\hline Dermographism & $1(0.8)$ & $0(0)$ & 1.000 \\
\hline Urticaria & $9(7.5)$ & $11(9.2)$ & 0.806 \\
\hline Melasma & $1(0.8)$ & $1(0.8)$ & 1.000 \\
\hline Tinea & $6(5)$ & $4(3.3)$ & 0.741 \\
\hline Raynaud phenomenon & $1(0.8)$ & $0(0)$ & 1.000 \\
\hline Neurotic excoriation & $2(1.7)$ & $0(0)$ & 0.496 \\
\hline Seborrheic dermatitis & $4(3.3)$ & $0(0)$ & 0.119 \\
\hline Contact dermatitis & $5(4.2)$ & $1(0.8)$ & 0.207 \\
\hline Acne & $3(2.5)$ & $5(4.2)$ & 0.717 \\
\hline Fibroma molle & $2(1.7)$ & $2(1.7)$ & 1.000 \\
\hline Lichen simplex chronicus & $6(5)$ & $1(0.8)$ & 0.114 \\
\hline Hair loss & $5(4.2)$ & $4(3.3)$ & 1.000 \\
\hline Molluscum contagiosum & $1(0.8)$ & $1(0.8)$ & 1.000 \\
\hline Rosacea & $0(0)$ & $1(0.8)$ & 1.000 \\
\hline Psoriasis & $1(0.8)$ & $2(1.7)$ & 1.000 \\
\hline Behçet's disease & $1(0.8)$ & $0(0)$ & 1.000 \\
\hline
\end{tabular}

Beck: Beck Depression Inventory; FIQ: Fibromyalgia Impact Questionnaire; FMS: Fibromyalgia Syndrome.
There was no significant difference between male FMS patients and healthy male participants about age $(p=0.933)$, marital status $(p=1.000)$ and educational status $(p=0.987)$. There was a statistically significant difference between male FMS patients and healthy male participants about BDI and FIQ scores $(p<0.001, p<0.001)$. This difference was due to high BDI and FIQ scores of male FMS patients. There was no significant difference between the two groups concerning dermatological diagnoses (Table 2).

There was no significant difference between male FMS patients and female FMS patients about $(p=0.931)$, marital status $(p=1.000)$ and educational status $(p=0.694)$.

Table 3. Comparison of the female group diagnosed with fibromyalgia syndrome and male group diagnosed with fibromyalgia syndrome

\begin{tabular}{|c|c|c|}
\hline & $\begin{array}{c}\text { FMS } \\
\text { Female }\end{array}$ & $\begin{array}{l}\text { FMS } \\
\text { Male }\end{array}$ \\
\hline Age median (Min-Max) & $41(30-50)$ & $40(30-50)$ \\
\hline \multicolumn{3}{|l|}{ Marital status } \\
\hline Single & $11(9.2)$ & $12(10)$ \\
\hline Married & $46(38.3)$ & $45(37.5)$ \\
\hline Widowed & $3(2.5)$ & $3(2.5)$ \\
\hline \multicolumn{3}{|l|}{ Educational status } \\
\hline Elementary & $27(22.5)$ & $20(16.7)$ \\
\hline Middle School & $19(15.8)$ & $20(16.7)$ \\
\hline High School & $7(5.8)$ & $11(9.2)$ \\
\hline University & $3(2.5)$ & $4(3.3)$ \\
\hline Doctorate & $4(3.3)$ & $5(4.2)$ \\
\hline Beck median (Min-Max) & $28.5(20-40)$ & $22(9-40)$ \\
\hline FEQ median (Min-Max) & $34.5(25-50)$ & $32(17-50)$ \\
\hline \multicolumn{3}{|c|}{ Dermatological diagnoses, n (\%) } \\
\hline Dermographism & $2(1.7)$ & $1(0.8)$ \\
\hline Urticaria & $12(10)$ & $9(7.5)$ \\
\hline Melasma & $4(3.3)$ & $1(0.8)$ \\
\hline Tinea & $5(4.2)$ & $6(5)$ \\
\hline Raynaud phenomenon & $2(1.7)$ & $1(0.8)$ \\
\hline Neurotic excoriation & $5(4.2)$ & $2(1.7)$ \\
\hline Seborrheic dermatitis & $2(1.7)$ & $4(3.3)$ \\
\hline Contact dermatitis & $5(4.2)$ & $5(4.2)$ \\
\hline Acne & $3(2.5)$ & $3(2.5)$ \\
\hline Fibroma molle & $3(2.5)$ & $2(1.7)$ \\
\hline Lichen simplex chronicus & $13(10.8)$ & $6(5)$ \\
\hline Hair loss & $2(1.7)$ & $5(4.2)$ \\
\hline Molluscum contagiosum & $2(1.7)$ & $1(0.8)$ \\
\hline Rosacea & $3(2.5)$ & $0(0)$ \\
\hline Psoriasis & $0(0)$ & $1(0.8)$ \\
\hline Behçet's disease & $0(0)$ & $1(0.8)$ \\
\hline
\end{tabular}

Beck: Beck Depression Inventory; FIQ: Fibromyalgia Impact Questionnaire. 
There was a statistically significant difference between the BDI scores of male FMS patients and female FMS patients $(p<0.001)$. Similarly, there was a significant difference between the FIQ scores of the two groups $(p=0.074)$. There was no significant difference between the two groups concerning dermatological diagnoses (Table 3 ).

\section{Discussion}

The present study aims to investigate whether there is a difference in dermatological findings between male and female FMS patients and healthy volunteers and between male and female FMS patients. The most significant result of our study was that the diagnosis of lichen simplex chronicus was significantly higher in female FMS patients than in healthy female participants $(p=0.006)$. This difference suggested that patients with FMS were more prone to dermatological diseases.

There was a statistically significant difference between BDI and FIQ scores of female FMS patients and healthy female participants $(p<0.001, p<0.001)$. However, this difference due to high BDI and FIQ scores in patients with FMS was an expected result due to the presence of the disease in the study group. In addition, there was a statistically significant difference between BDI and FIQ scores of male FMS patients and healthy male participants $(p<0.001, p<0.001)$. These results were also an expected result due to the diagnosis of FMS. There was a significant difference between female FMS patients and male FMS patients concerning BDI scores $(p<0.001)$. This result revealed that female FMS patients were more prone to depression. In addition, BDI and FIQ scores in both female and male FMS patients were found to be consistent with the BDI and FIQ scores in the literature ${ }^{[10,11]}$.

Previous studies have reported increased mast cell counts, inflammatory cytokines, opioid receptors, dysfunctional mitochondria, and structural and functional disorders in the skin of patients with FMS. In studies with no increase in mast cell count, mast cell degranulation and immunoglobulin $G$ levels were found to be increased. An increase in interleukin $1 \beta$, interleukin- 6 , tumor necrosis factor- $\alpha$, and oxidative stress parameters and a decrease in coenzyme Q10 levels were detected in the skin samples. Therefore, dermatological findings in FMS patients vary widely [12-14]. In a study by Laniosz et al. ${ }^{[15]}$ with 825 FMS patients, no dermatological diagnosis was dominant in this population, except for a subjective increase in sweating (32\%). In the same study, patients diagnosed with lichen simplex chronicus were found to constitute $0.5 \%$ of the FMS population, whereas, in our study, patients with lichen simplex chron- icus were found to constitute $10.5 \%$ of the female FMS group and $5 \%$ of the male FMS group.

In a study by Thune, only 35 of 105 patients with FMS had a previous diagnosis of psoriasis ${ }^{[16]}$. In our study, the patients diagnosed with psoriasis were found to constitute $0.5 \%$ of the male FMS group, and psoriasis was not detected in the female FMS group.

In a study by Torresani et al.,. ${ }^{[17]}$ chronic urticaria was found in $70 \%$ of the $126 \mathrm{FMS}$ patients. Yener et al. ${ }^{[18]}$ investigated the rate of FMS in 72 patients with chronic urticaria. In this study, there was no significant difference between the rate of FMS in the control group and in patients with chronic urticaria. However, this rate was found to be $10 \%$ in the female FMS group and $7.5 \%$ in the male FMS group in our study. Future studies with larger sample sizes are needed to investigate this issue.

In a study by Erdogan et al., ${ }^{[19]} 105$ FMS patients and 105 healthy volunteers were compared concerning xerosis, dermographism, lichen simplex chronicus, neurotic excoriations, tinea pedis, and seborrheic dermatitis. These diagnoses were significantly higher in the FMS group than in the control group. In our study, the rate of lichen simplex chronicus diagnosis in the female FMS group was found to be $10.5 \%$. This rate was significantly higher than that in healthy female participants.

In our study, lichen simplex chronicus was found to be more common in the FMS group. In addition, BDI scores were also significantly higher in the female FMS group than in the female control and male FMS groups. In other studies, lichen simplex chronicus has been usually comorbid with obsessive-compulsive disease and anxiety. Similarly, FMS has been associated with major depression, anxiety, and psychiatric disorders ${ }^{[20-23]}$. This explains why lichen simplex chronicus is more common in the female FMS group.

\section{Conclusion}

In our study, we found that lichen simplex chronicus was more common in female patients with FMS. When evaluating patients with FMS, clinicians should follow a holistic approach both psychologically and dermatologically and increase their awareness in this respect.

Ethics Committee Approval: Kanuni Sultan Süleyman Training and Research Hospital KAEK/2018.5.06.

Peer-review: Externally peer-reviewed.

Authorship Contributions: Concept: Ö.T.; Design: B.Ü.; Data Collection or Processing: E.A.; Analysis or Interpretation: M.E.; Literature Search: I.A.Ş.; Writing: Ö.T., M.K. 
Conflict of Interest: None declared.

Financial Disclosure: The authors declared that this study received no financial support.

\section{References}

1. Krype L L. Fibromyalgia: A review of its pathophysiology and drug treatment. J Pharm Pract 2009;22:6-16. [CrossRef]

2. Yunus MB. Fibromyalgia and overlapping disorders: the unifying concept of central sensitivity syndromes. Semin Arthritis Rheum 2007;36:339-56. [CrossRef]

3. Blanco I, Béritze N, Argüelles M, Cárcaba V, Fernández F, Janciauskiene $S$, et al. Abnormal overexpression of mastocytes in skin biopsies of fibromyalgia patients. Clin Rheumatol 2010;29:1403-12. [CrossRef]

4. Kim SH. Skin biopsy findings: implications for the pathophysiology of fibromyalgia. Med Hypotheses 2007;69:141-4.

5. Salemi S, Rethage J, Wollina U, Michel BA, Gay RE, Gay S, et al. Detection of interleukin 1 beta (IL-1beta), IL-6, and tumor necrosis factor-alpha in skin of patients with fibromyalgia. J Rheumatol 2003;30:146-50.

6. Sprott H, Müller A, Heine H. Collagen cross-links in fibromyalgia syndrome. Z Rheumatol 1998;57:52-5. [CrossRef]

7. Cakir T, Evcik D, Dundar U, Yigit I, Kavuncu V. Evaluation of sympathetic skin response and $F$ wave in fibromyalgia syndrome patients. Turkish Journal of Rheumatology 2011;26:6p.

8. Ozgocmen S, Yoldas T, Yigiter R, Kaya A, Ardicoglu O. R-R interval variation and sympathetic skin response in fibromyalgia. Arch Med Res 2006;37:630-4. [CrossRef]

9. Wolfe F, Clauw DJ, Fitzcharles MA, Goldenberg DL, Häuser W, Katz RL, et al. 2016 Revisions to the 2010/2011 fibromyalgia diagnostic criteria. Semin Arthritis Rheum 2016;46:319-29.

10. Lee JW, Lee KE, Park DJ, Kim SH, Nah SS, Lee JH, et al. Determinants of quality of life in patients with fibromyalgia: A structural equation modeling approach. PLoS One 2017;12:e0171186.

11. Alev A, Mihriban A, Bilge E, Ayça E, Merve K, Şeyma C, et al. Effects of whole body vibration therapy in pain, function and depression of the patients with fibromyalgia. Complement Ther Clin Pract 2017;28:200-3. [CrossRef]
12. Eneström S, Bengtsson A, Frödin T. Dermal lgG deposits and increase of mast cells in patients with fibromyalgia--relevant findings or epiphenomena? Scand J Rheumatol 1997;26:30813. [CrossRef]

13. Cordero MD, Moreno-Fernández AM, Carmona-López MI, Sánchez-Alcázar JA, Rodríguez AF, Navas $P$, et al. Mitochondrial dysfunction in skin biopsies and blood mononuclear cells from two cases of fibromyalgia patients. Clin Biochem 2010;43:1174-6. [CrossRef]

14. Cordero MD, Díaz-Parrado $E$, Carrión AM, Alfonsi $S$, Sánchez-Alcazar JA, Bullón P, et al. Is inflammation a mitochondrial dysfunction-dependent event in fibromyalgia? Antioxid Redox Signal 2013;18:800-7. [CrossRef]

15. Laniosz V, Wetter DA, Godar DA. Dermatologic manifestations of fibromyalgia. Clin Rheumatol 2014;33:1009-13. [CrossRef]

16. Thune PO. The prevalence of fibromyalgia among patients with psoriasis. Acta Derm Venereol 2005;85:33-7. [CrossRef]

17. Torresani C, Bellafiore S, De Panfilis G. Chronic urticaria is usually associated with fibromyalgia syndrome. Acta Derm Venereol 2009;89:389-92. [CrossRef]

18. Yener M, Erturan I, Ceyhan AM, Inal EE, Kazanoglu OO. The evaluation of prevalence of fibromyalgia in patients with chronic urticaria. Med Sci Monit 2013;19:757-61. [CrossRef]

19. Erdogan HK, Sas S, Acer E, Bulur I, Altunay IK, Erdem HR. Cutaneous findings in fibromyalgia syndrome and their effect on quality of life. Dermatologica Sinica 2016;34:131-4. [CrossRef]

20. Braun-Falco O, Plewig G, Wolff HH, Landthaler M. Pruritis and Prurigo. 3rd ed. Italy: Springer Verlag; 2009. p. 446.

21. Millard LG, Cotterill JA. Psychocutaneous Disorders. In: Burns T, Breahnach S, Lox N, Griffiths C (editors). Rook's Textbook of Dermatology. 7th ed. Massachusetts: Blackwell Science Publ; 2004. p. 1-41.

22. Liao YH, Lin CC, Tsai PP, Shen WC, Sung FC, Kao CH. Increased risk of lichen simplex chronicus in people with anxiety disorder: a nationwide population-based retrospective cohort study. Br J Dermatol 2014;170:890-4. [CrossRef]

23. Kirmayer LJ, Robbins JM, Kapusta MA. Somatization and depression in fibromyalgia syndrome. Am J Psychiatry 1988;145:950-4. [CrossRef] 